\title{
Apolipoprotein A-I Is Required for Cholesteryl Ester Accumulation in Steroidogenic Cells and for Normal Adrenal Steroid Production
}

\author{
Andrew S. Plump, ${ }^{\star}$ Sandra K. Erickson, ${ }^{\ddagger}$ Wei Weng, ${ }^{\star}$ Jacqueline S. Partin, ${ }^{\S}$ Jan L. Breslow, ${ }^{\star}$ and David L. Williams ${ }^{\S}$ \\ *Laboratory of Biochemical Genetics and Metabolism, The Rockefeller University, New York 10021; ${ }^{\ddagger}$ Department of Medicine, \\ University of California at San Francisco and Veterans Affairs Medical Center, San Francisco, California $94143 ;$ and ${ }^{\S}$ Department of \\ Pharmacological Sciences, University Medical Center, State University of New York at Stony Brook, Stony Brook, New York 11794
}

\begin{abstract}
In addition to its ability to remove cholesterol from cells, HDL also delivers cholesterol to cells through a poorly defined process in which cholesteryl esters are selectively transferred from HDL particles into the cell without the uptake and degradation of the lipoprotein particle. The HDLcholesteryl ester selective uptake pathway is known to occur in human, rabbit, and rodent hepatocytes where it may contribute to the clearance of plasma cholesteryl ester. The selective uptake pathway has been studied most extensively in steroidogenic cells of rodents in which it accounts for $90 \%$ or more of the cholesterol destined for steroid production or cholesteryl ester accumulation. In this study we have used apo A-I-, apo A-II-, and apo E-deficient mice created by gene targeting in embryonic stem cells to test the importance of the three major HDL proteins in determining cholesteryl ester accumulation in steroidogenic cells of the adrenal gland, ovary, and testis. apo E and apo A-II deficiencies were found to have only modest effects on cholesteryl ester accumulation. In contrast, apo A-I deficiency caused an almost complete failure to accumulate cholesteryl ester in steroidogenic cells. These results suggest that apo A-I is essential for the selective uptake of HDL-cholesteryl esters. The lack of apo A-I has a major impact on adrenal gland physiology causing diminished basal corticosteroid production, a blunted steroidogenic response to stress, and increased expression of compensatory pathways to provide cholesterol substrate for steroid production. (J. Clin. Invest. 1996. 97: 2660-2671.) Key words: high density lipoprotein • selective uptake • corticosteroids • apolipoprotein-deficient mice
\end{abstract}

\section{Introduction}

The inverse correlation between HDL levels and coronary heart disease in humans suggests that HDL has a protective effect against the development of atherosclerosis $(1,2)$. This premise is supported by recent studies showing that over-

Address correspondence to David L. Williams, Department of Pharmacological Sciences, University Medical Center, State University of New York at Stony Brook, Stony Brook, NY 11794. Phone: 516-4443083; FAX: 516-444-3218.

Received for publication 11 January 1996 and accepted in revised form 6 March 1996.

The Journal of Clinical Investigation

Volume 97, Number 11, June, 1996, 2660-2671 expression of human apo A-I in transgenic mice protects against the development of fatty streak lesions (3) and decreases the extent of atherosclerosis in apo E-deficient $(4,5)$ and apo(a)-transgenic mice (6). These effects of HDL may arise through an early step in the reverse cholesterol transport process (7) in which HDL facilitates the removal of cholesterol from cells by acting as an acceptor of free cholesterol that desorbs from the cell membrane (8). This activity of HDL may be crucial in preventing the accumulation of cholesterol and cholesteryl ester in the arterial wall as occurs in atherosclerosis. In addition to cholesterol removal from cells, HDL also delivers cholesterol to cells through a poorly defined process in which cholesteryl esters are selectively transferred from HDL particles into the cell without the uptake and degradation of the lipoprotein particle. The HDL-cholesteryl ester selective uptake pathway is known to occur in human, rabbit, and rodent hepatocytes (9-15) where it may contribute to the clearance of plasma cholesteryl ester. The HDL selective uptake pathway occurs most prominently in steroidogenic cells of mice and rats in which it accounts for $90 \%$ or more of the cholesterol destined for steroid production or cholesteryl ester accumulation, particularly in the adrenal gland. Early studies by Gwynne et al. (16), Andersen and Dietschy (17), and Kovanen et al. (18) showed that adrenal glands of rats and mice could use both LDL and HDL as a source of lipoprotein cholesterol, but HDL was significantly more effective in supplying cholesterol for cholesteryl ester accumulation and corticosterone production. Gwynne and Hess (19) further demonstrated that the HDL-mediated increase in corticosterone production in rat adrenocortical cells greatly exceeded what could be accounted for by HDL particle uptake. Subsequent studies in cell culture and in vivo have shown directly that the majority of HDL-cholesteryl ester uptake by adrenal cells occurs without particle uptake $(10-12,14)$. These data are the basis for the hypothesis that the HDL selective uptake pathway is the primary pathway by which steroidogenic cells acquire cholesterol.

Despite a variety of attempts to understand the mechanism of the HDL selective uptake process, there has been little success in defining the protein participants on the cell surface or on the lipoprotein particle. In this study we have used apo A-I-, apo A-II-, and apo E-deficient mice created by gene targeting in embryonic stem cells to test the importance of the three major HDL proteins in determining cholesteryl ester accumulation in steroidogenic cells of the adrenal gland, ovary, and testis. apo E and apo A-II deficiencies were found to have only modest effects on cholesteryl ester accumulation. In contrast, apo A-I deficiency caused an almost complete failure to accumulate cholesteryl ester in steroidogenic cells. The lack of apo A-I has a major impact on adrenal gland physiology causing diminished basal corticosteroid production, a blunted steroidogenic response to stress, and increased expression of 
compensatory pathways to provide cholesterol substrate for steroid production.

\section{Methods}

Animals. apo A-I-deficient (20) and apo A-II-deficient (21) mice were created by gene targeting in embryonic stem cells as described. Detailed characterization of the apo A-I- and apo A-II-deficient mice will be presented elsewhere (Plump, A.S., T. Hayek, A. Walsh, and J.L. Breslow, manuscript submitted for publication and Weng, W., T. Hayek, and J.L. Breslow, manuscript in preparation). apo E-deficient mice were from the Rockefeller University colony (22). Control, apo A-I-deficient, apo A-II-deficient, and apo E-deficient mice were on an outbred $129 \times \mathrm{C} 57 \mathrm{Bl} / 6$ hybrid genetic background. The compound apo A-I- and apo E-deficient mice were the second and third generation progeny from a homozygous apo E-deficient and homozygous apo A-I-deficient parental cross. apo E-deficient mice were screened by PCR. apo A-I-deficient mice were screened by genomic Southern blot and/or Ouchterlony immunodiffusion using a polyclonal chicken anti-mouse antibody supplied by Neal Azrolan (The Rockefeller University).

Experimental treatments. Mice received standard mouse chow and water ad libitum and were maintained on $12 \mathrm{~h}$ light $/ 12 \mathrm{~h}$ dark cycle. Experiments were initiated $2 \mathrm{~h}$ into the light period. For the swim stress test (23), each mouse was bled from the retroorbital plexus into EDTA-coated tubes immediately before and after the test which consisted of a 3-min swim at $5^{\circ} \mathrm{C}$ followed by a 17 -min rest at room temperature. For the ACTH test, mice were untreated or received an intraperitoneal injection of either $0.2 \mathrm{ml}$ saline or $0.2 \mathrm{ml}$ saline containing $100 \mathrm{mU}$ ACTH (24) (Acthar, Rorer Pharmaceuticals, Fort Washington, PA). Males and one group of females received one $\mathrm{ACTH}$ injection, and one group of females received three sequential ACTH injections at hourly intervals. Mice were killed $40 \mathrm{~min}$ after the last injection by cervical dislocation and bled from the thoracic cavity. For the dexamethasone suppression test, mice received four subcutaneous injections of $0.1 \mathrm{ml}$ saline or $0.1 \mathrm{ml}$ saline containing 40 $\mu \mathrm{g}$ dexamethasone phosphate (Elkins-Sinn, Inc., Cherry Hill, NJ) at 12-h intervals. Mice were killed $12 \mathrm{~h}$ after the last injection.

Tissue preparation and microscopy. For light microscopy, mice were perfused through the left ventricle with PBS followed by $4 \%$ formaldehyde in PBS. After overnight fixation in $4 \%$ formaldehyde in PBS, adrenal glands and ovaries were infiltrated with three changes of $30 \%$ sucrose in PBS and quick frozen in Tissue-Tec OCT (Miles, Elkhart, IN). 4-6- $\mu \mathrm{m}$-thick cryostat sections were placed on poly-L-lysine (Sigma Chemical Co., St. Louis, MO)-coated slides, stained with oil red $\mathrm{O}$, and lightly counterstained with hematoxylin (25). Sections were examined with a Zeiss Universal microscope equipped with an Optronics VI 470 color camera. Images were processed with Image I software and printed with a Tektronix Phaser II SDX color printer.

For electron microscopy, three wild-type and apo A-I-deficient mice were perfused at constant pressure $(110 \mathrm{mmHg})$ through the left ventricle first with $0.5 \mathrm{ml} 0.1 \mathrm{M}$ sodium cacodylate, $\mathrm{pH} 7.4$, followed by $25 \mathrm{ml}$ freshly prepared $2 \%$ glutaraldehyde, $1 \%$ paraformaldehyde in $0.1 \mathrm{M}$ sodium cacodylate, $\mathrm{pH}$ 7.4. To facilitate orientation during sectioning, a 1-mm disk from the center of the gland was cut into a pie shaped wedge with the point in the medulla. Adrenal wedges were postfixed with reduced osmium (1\% aqueous osmium tetroxide, $1.5 \%$ potassium ferrocyanide) followed by block stain with $2 \%$ aqueous uranyl acetate. Samples were dehydrated through acetone and embedded in Epon. Two blocks from each animal were cut at $70 \mathrm{~nm}$ on an RMC 6000 ultramicrotome, mounted on 300-mesh copper grids, stained with lead citrate, and viewed with a JOEL 1200EX analytical microscope operating at $80 \mathrm{kV}$. After locating the center of the zona fasciculata at low power, photographs of microvillar channels were made at $\times 50,000$ and enlarged two times. Microvillar channel width was determined as the distance between the outer membrane leaflets of juxtaposed microvilli forming the channel, using a $6 \times$ loupe with graticle. Measurements were made on multiple sections from each block for each animal. 160 measurements were made on wild-type mice and 128 on apo A-I-deficient mice.

To determine whether the total microvillar surface area of zona fasciculata cells was changed in apo A-I-deficient mice, using sections from each block, the entire perimeter of several sinusoids was photographed at $\times 20,000$ and enlarged two times. The micrographs were scanned with the HP SCANJET program via Adobe Photoshop, and membrane length measurements were made along the subendothelial face of the zona fasciculata cells with NIH IMAGE software. For each cell the ratio of total microvillar membrane length to the linear distance along the cell was calculated. Total linear membrane length measured was $185 \mu \mathrm{m}$ for wild-type mice and $227 \mu \mathrm{m}$ for apo A-Ideficient mice.

Plasma corticosteroids, adrenal gland HMG CoA reductase activity, $L D L$ receptor, and apo $E$. Corticosteroids were measured as fluorogenic steroids following methylene chloride extraction as described by Kowal and Fiedler (26) using corticosterone as standard. Microsomes were prepared from adrenal glands pooled from 10 animals as described (27) except that aprotinin $(10 \mu \mathrm{g} / \mathrm{ml})$ was included in all buffers. Aliquots were assayed for HMG CoA reductase activity (27) and for LDL receptor and apo E by Western blotting $(27,28)$ using rabbit antisera provided by Dr. Janet Boyles for the LDL receptor and by Dr. Karl Weisgraber for apo E (The Gladstone Foundation Laboratories, San Francisco, CA). All assays were performed at least twice. Results for reductase are expressed as pmol mevalonate $\mathrm{min}^{-1} \mathrm{mg}$ protein ${ }^{-1}$, and for LDL receptor and apo $\mathrm{E}$ as units $\mathrm{mg}$ protein $^{-1}$. Units are derived from densitometry and are relative to values (set as 1.00) for standard rat liver microsomes (LDL receptor) or standard rat sera (apo E). Both standards are from pooled samples from Sprague-Dawley male rats fed a chow diet. Aliquots of the standard were included in each Western blot.

Plasma and adrenal cholesterol and cholesteryl ester. Animals were anesthetized with pentobarbital and perfused with $0.15 \mathrm{M} \mathrm{NaCl}, 0.001 \mathrm{M}$ EDTA via the left ventricle. Adrenal glands were dissected free of adipose tissue, rinsed in perfusion buffer, blotted dry, and weighed. Adrenal glands were cut into small pieces, combined with a predetermined amount of coprostanol as an internal standard, and extracted overnight in chloroform/methanol (2:1). After washing with water, the organic phase was dried under $\mathrm{N}_{2}$, dissolved in carbon disulfide, and separated on 100/120 chromosorb WHP coated with 3\% OV-17 (Supelco Inc., Bellefonte, PA) in a gas chromatograph (Perkin Elmer Corp., Norwalk, CT) in order to quantify free cholesterol. Parallel samples were saponified and analyzed for total cholesterol; cholesteryl ester was determined as the difference between total and free cholesterol. Data are expressed as micrograms of cholesterol per milligram of tissue weight. Plasma HDL (1.063 grams $/ \mathrm{ml}<\rho<1.21$ grams $/ \mathrm{ml}$ ) was isolated by ultracentrifugation (29), and samples pooled from wild-type, apo A-I-, or apo A-II-deficient mice were analyzed for total and free cholesterol by gas chromatography as described above. HDL samples from individual mice were analyzed for total cholesterol, and the cholesteryl ester content was calculated using the mean percent cholesteryl ester content in the pooled samples (wild-type, 81\%; apo A-I-deficient, 51\%; apo A-II-deficient, 81\%).

\section{Results}

Cholesteryl ester accumulation in apo A-I-deficient mice. Gross examination of adrenal glands from apo A-I-deficient mice revealed a flesh-colored organ in contrast to the white appearance of glands from wild-type mice (Fig. $1 A$ ). Hemisection of wild-type adrenal glands showed the white appearance in the cortex whereas the medulla was flesh colored. In contrast, hemisection of apo A-I-deficient adrenal glands revealed a uniform fleshy appearance with a poorly discernible margin between cortex and medulla. To determine whether this difference in gross appearance reflected a difference in 

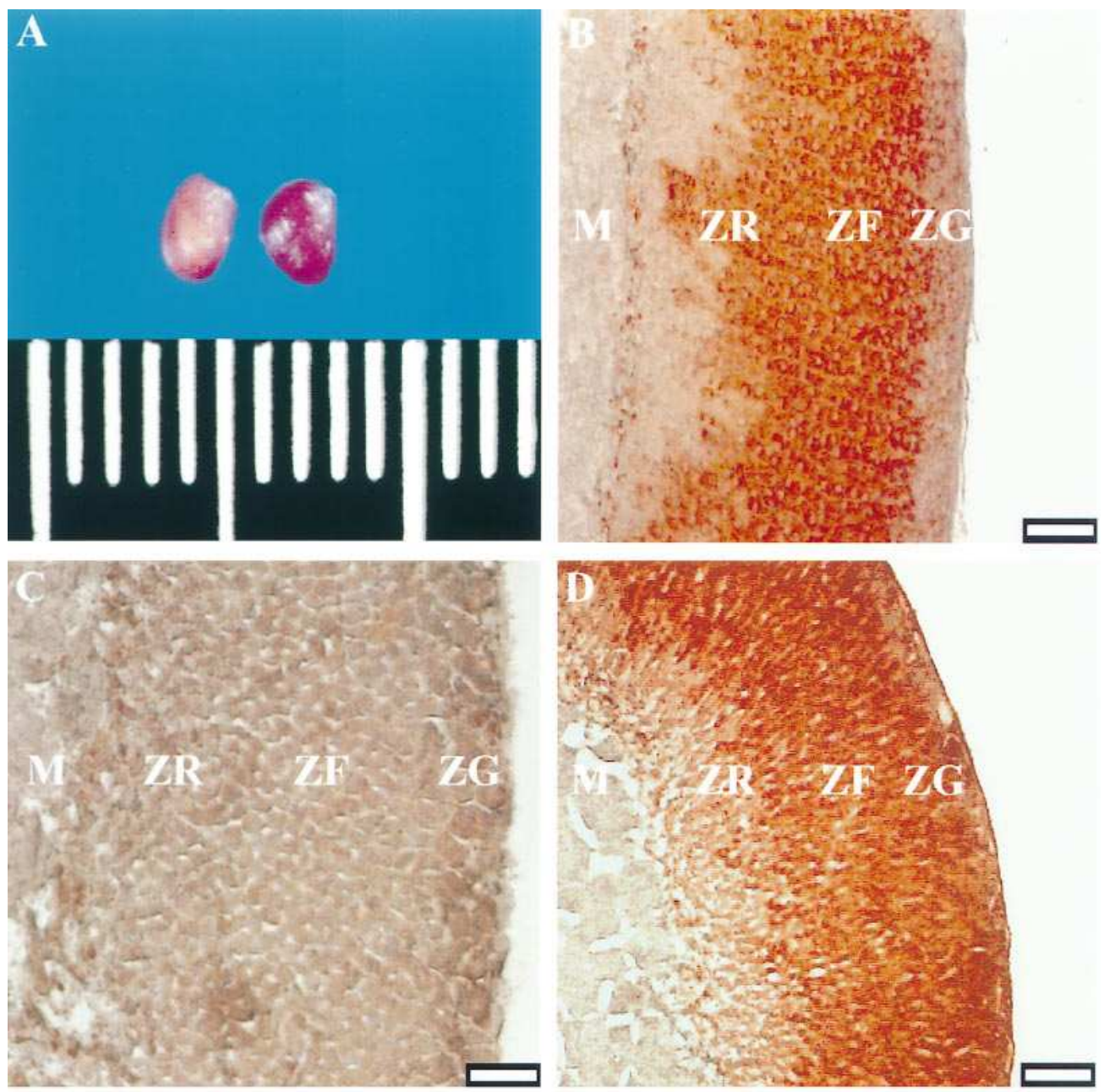

Figure 1. Oil red O staining of adrenal glands from wild-type and apolipoprotein-deficient mice. $(A)$ Gross morphology of wild-type (left) and apo A-Ideficient (right) adrenal glands. Note white appearance of the lipid-laden wild-type gland and the pink flesh color of the lipidpoor apo A-I-deficient gland. Ruler divisions are millimeters. $(B-F)$ Cross sections of adrenal glands were stained with oil red $\mathrm{O}$ and counterstained with hematoxylin. $Z G$, zona glomerulosa; $Z F$, zona fasciculata; $Z R$, zona reticularis; $M$, medulla; scale bars are $250 \mu \mathrm{m}$. (B) Wildtype; $(C)$ apo A-I-deficient; $(D)$ apo A-II-deficient; $(E)$ apo E-deficient; $(F)$ double homozygous apo A-I- and apo E-deficient.

cholesteryl ester accumulation, cryostat sections were stained with oil red $\mathrm{O}$, a dye that detects primarily cholesteryl ester droplets in adrenocortical cells (25, 30-32). A cross section through a wild-type adrenal gland (Fig. $1 B$ ) shows prominent oil red $\mathrm{O}$ staining in the cortex but none in the medulla. Lipid droplets are abundant and fill the cytoplasm of cells in the zona fasciculata and zona reticularis but are much less abundant in zona glomerulosa cells. In contrast, cortical cells of the apo A-I-deficient gland (Fig. $1 C$ ) are essentially devoid of lipid staining. The section shown in Fig. $1 C$ is typical of male apo A-I-deficient mice. A small amount of oil red O staining was seen in the outermost region of the zona fasciculata in some female apo A-I-deficient glands, but most of the cortex was as devoid of oil red $\mathrm{O}$ staining as in the male. Electron microscopic examination of typical zona fasciculata cells confirmed an abundance of lipid droplets in wild-type glands (Fig. $2 A)$ and the near absence of adrenocortical lipid droplets in the apo A-I-deficient mouse (Fig. 2 B).

The extent of cholesteryl ester depletion in apo A-I-deficient mice was determined by gas chromatographic analysis of 

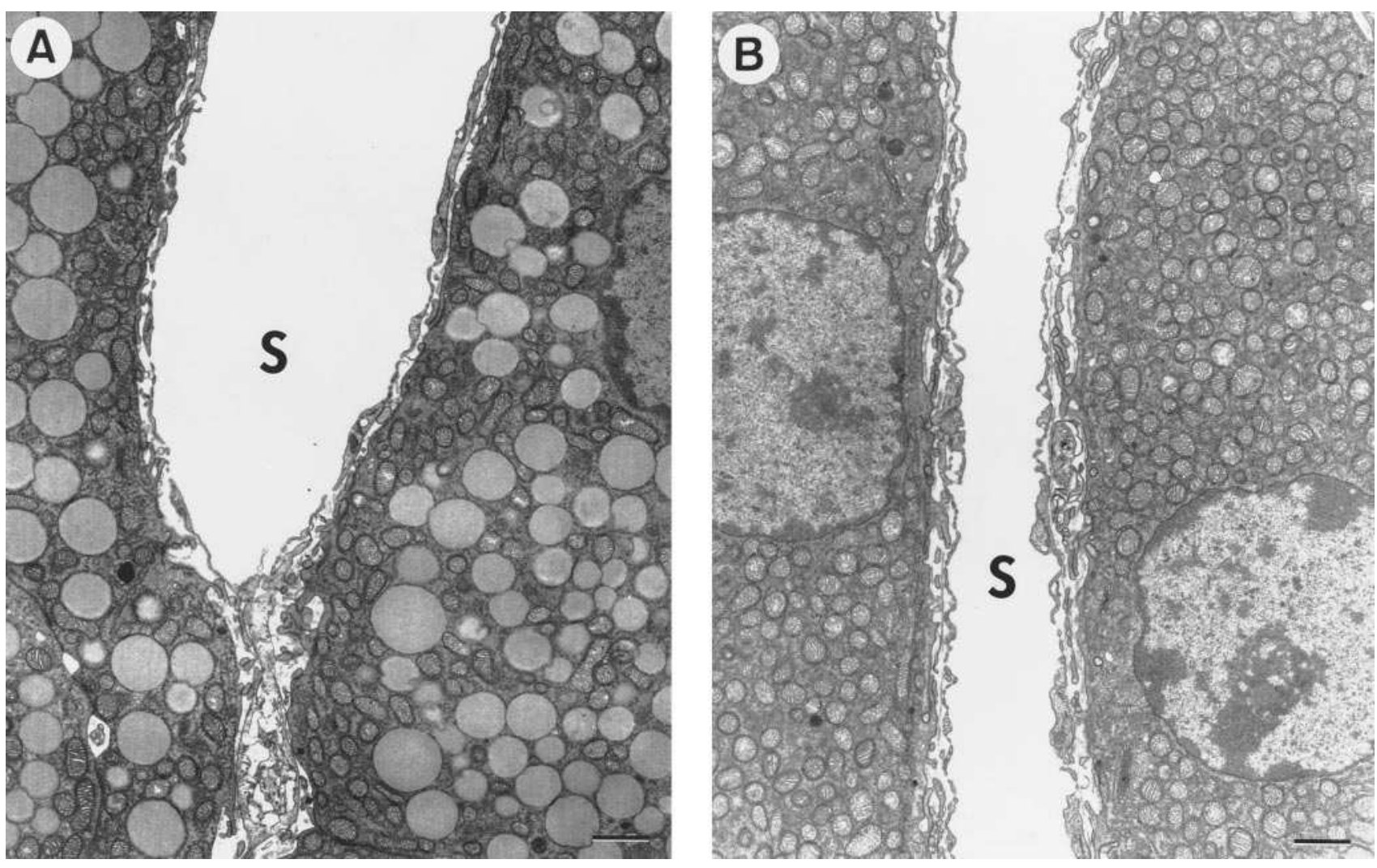

Figure 2. Electron micrographs of zona fasciculata cells from wild-type and apo A-I-deficient mice. $(A)$ Micrograph of wild-type zona fasciculata cells showing abundant cytoplasmic lipid droplets. $(B)$ Zona fasciculata cells from apo A-I-deficient mouse showing absence of lipid droplets. $S$, sinusoid. Scale bars are $1 \mu \mathrm{m}$.

adrenal lipid extracts. When normalized to tissue wet weight, the free cholesterol content was similar between wild-type and apo A-I-deficient mice (data not shown); however, there were dramatic differences in cholesteryl ester content (Fig. $3 A$ ). The cholesteryl ester content of apo A-I-deficient adrenal glands was reduced by 28 -fold in males and 25 -fold in females. Thus, in the absence of plasma apo A-I adrenocortical cells do not accumulate significant amounts of cholesteryl ester.

To determine whether this deficiency in cholesteryl ester accumulation extended to other steroidogenic cells, the cholesteryl ester contents of ovaries and testes were also measured. As shown in Fig. $3 \mathrm{~B}$, the cholesteryl ester content of mature cycling ovaries was reduced sixfold in apo A-I-deficient mice. To determine which ovarian cell types were depleted of cholesteryl ester in apo A-I-deficient mice, cryosections of perfusion fixed ovaries were stained with oil red $\mathrm{O}$. In the wild-type ovary (Fig. 4, $A, C$, and $E$ ), corpora lutea, interstitial cells, and theca cells contain abundant lipid droplets while granulosa cells are unstained. In the apo A-I-deficient ovary (Fig. 4, $B$, $D$, and $F$ ), corpora lutea show little or no stain (Fig. $4, A$ versus $B ; E$ versus $F$ ), theca cells are devoid of stain, and interstitial cells show greatly reduced stain (Fig. $4, C$ versus $D$ ). In the testis, Leydig cells are such a small fraction of the cells that measurements of testis cholesteryl ester showed no difference between wild-type and apo A-I-deficient mice (Fig. $3 \mathrm{~B}$ ). However, oil red $\mathrm{O}$ staining showed that the lipid droplets normally seen only in Leydig cells in wild-type animals (Fig. 5, $A$ and $B$ ) were reduced or absent in apo A-I-deficient mice (Fig. $5, C$ and $D$ ). These data indicate that the absence of plasma apo A-I leads to a dramatic reduction in cholesteryl ester accumulation in cells of the adrenal gland, ovary, and testis that carry out de novo steroid synthesis from cholesterol.

The lack of cholesteryl ester accumulation in adrenocortical cells of apo A-I-deficient mice could reflect an inherent defect in their ability to store cholesteryl esters or could reflect a role of apo A-I in the process by which these cells acquire lipoprotein cholesterol. The ability of adrenocortical cells to store cholesteryl esters was assessed by administering exogenous glucocorticoid (dexamethasone) to suppress adrenal corticosteroid synthesis via feedback inhibition at the hypothalamicpituitary axis. By suppressing corticosteroid synthesis, we asked whether adrenals from apo A-I-deficient mice could shunt precursor cholesterol into cholesteryl ester stores. As shown in Table I, after $48 \mathrm{~h}$ of dexamethasone treatment, plasma corticosteroids were reduced by four- to fivefold in males and almost twofold in females as compared with salineinjected controls, indicating suppression of the hypothalamicpituitary-adrenal axis. Adrenal free cholesterol content was largely unchanged by dexamethasone treatment, but cholesteryl ester content was increased 10-fold in apo A-I-deficient males and 3.5-fold in females. After dexamethasone treatment, the cholesteryl ester content of apo A-I-deficient male adrenal glands was $41 \%$ of the value for the saline-injected wild-type males and $22 \%$ of the value of the dexamethasone- 

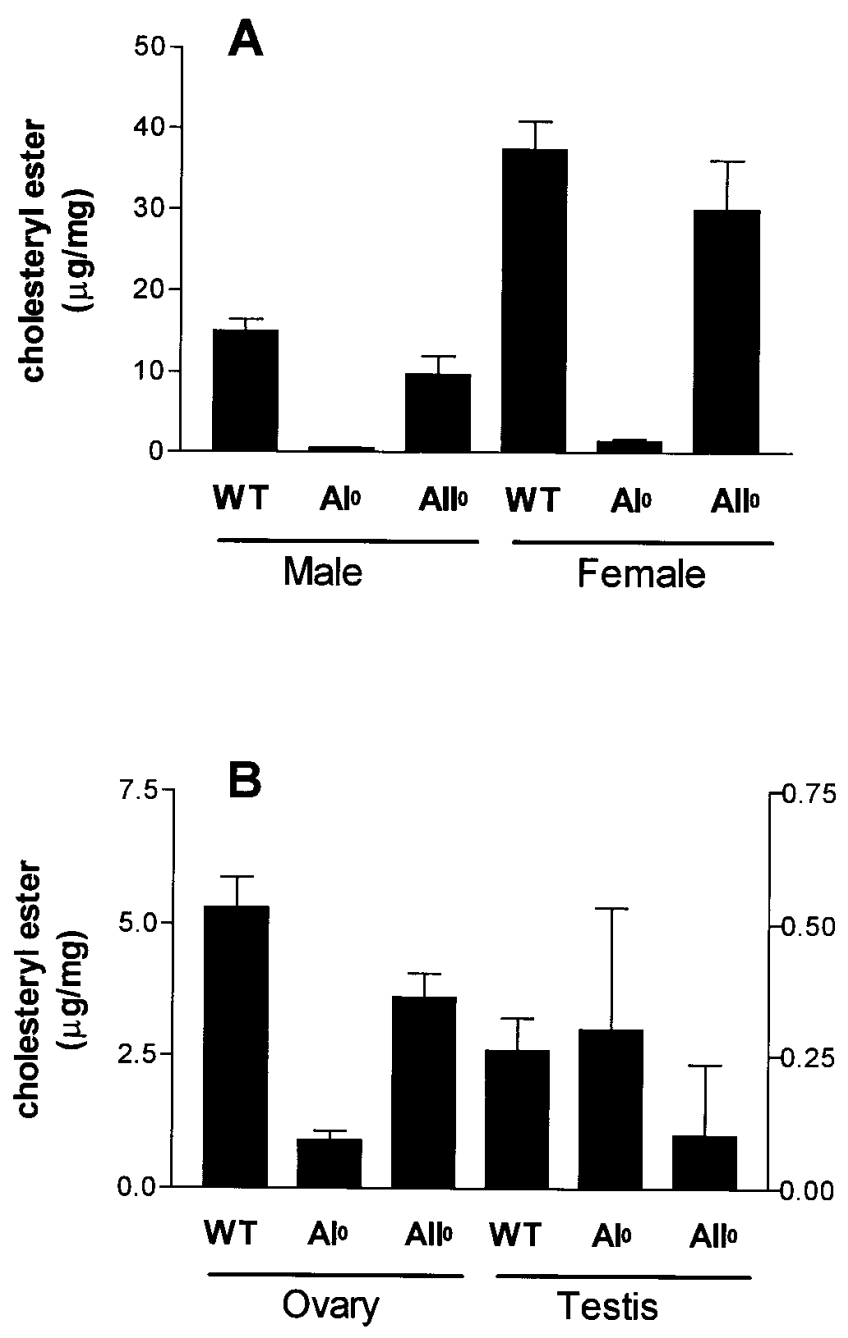

Figure 3. Cholesteryl ester content of adrenal gland, ovary, and testis. $(A)$ Adrenal gland cholesteryl ester content ( $\mu \mathrm{g} / \mathrm{mg}$ wet weight) in wild-type $(W T)$, apo A-I-deficient $\left(A I^{0}\right)$, and apo A-II-deficient $\left(A I I^{0}\right)$ mice. Error bar $=\mathrm{SD} .(B)$ Cholesteryl ester content of ovary (left ordinate) and testis (right ordinate). Other designations as in $A$.

injected wild-type males. These results indicate that adrenocortical cells of apo A-I-deficient mice are able to store significant quantities of cholesteryl ester when the demand for steroid production is reduced.

The deficiency in cholesteryl ester accumulation in steroidogenic cells of apo A-I-deficient mice could reflect a direct role of apo A-I in the acquisition of lipoprotein cholesterol or could indirectly reflect the reduced levels of HDL in these animals. To examine this point, we determined cholesteryl ester accumulation in steroidogenic cells of the apo A-II-deficient mouse that also has reduced plasma HDL. As shown in Fig. 6, the apo A-I-deficient mouse has $30 \%$ the level of HDL-cholesterol and $20 \%$ the level of HDL-cholesteryl ester as the wild-type mouse. As compared with the apo A-I-deficient mouse, the apo A-II-deficient mouse has even lower HDLcholesterol and an equivalent level of HDL-cholesteryl ester. Examination of the adrenal gland of the apo A-II-deficient mouse (Fig. $1 D$ ) showed little difference in oil red $\mathrm{O}$ staining as compared with wild-type cells (Fig. $1 B$ ) and dramatically more staining compared with apo A-I-deficient adrenocortical cells (Fig. $1 C$ ). This result is also reflected in cholesteryl ester measurements (Fig. $3 A$ ) which showed the adrenal glands of male and female apo A-II-deficient mice to have 60 and $80 \%$, respectively, of the wild-type content of cholesteryl ester. A similar result was seen in the Leydig cells of the testis which showed wild-type levels of oil red $\mathrm{O}$ staining in apo A-II-deficient mice (Fig. 5, $E$ and $F$ versus $A$ and $B$ ) as compared with the diminished staining in the apo A-I-deficient mice (Fig. 5, $C$ and $D$ ). Cells of the corpora luteum of apo A-II-deficient mice also showed normal oil red $\mathrm{O}$ staining (Fig. 5, $G$ versus $H$ ), and cholesterol measurements showed the ovary of the apo A-IIdeficient mouse to have $75 \%$ of the wild-type level of cholesteryl ester (Fig. $3 \mathrm{~B}$ ). These data indicate that despite having similarly reduced plasma HDL-cholesterol and -cholesteryl ester as the apo A-I-deficient mouse, the apo A-II-deficient mouse has near normal cholesteryl ester levels in the steroidogenic cells of the adrenal gland, ovary, and testis. These results indicate that the severe reduction in cholesteryl ester accumulation in steroidogenic cells of the apo A-I-deficient mouse is specific to the absence of apo A-I and not simply due to the reduction in HDL levels.

Adrenocortical cells are believed to obtain HDL-cholesteryl ester via the selective uptake pathway in which free and esterified cholesterol are transferred from HDL particles into the cell without uptake and degradation of the particle. This process is believed to occur in specialized HDL-filled microvillar channels that are formed by juxtaposition of adjacent microvilli (33). Microvillar channels are abundant in the subendothelial space immediately adjacent to the sinusoid. To determine whether the microvillar compartment was altered in apo A-I-deficient mice, adrenal glands were perfusion fixed in situ and examined by transmission electron microscopy. Fig. 7 $A$ is a micrograph of a typical microvillar channel filled with presumptive HDL particles (arrowheads) on a zona fasciculata cell from a wild-type animal. In contrast, microvillar channels from apo A-I-deficient animals (Fig. 7, B-D) appear to lack HDL particles. In addition, the width of the microvillar channel as measured by the distance between opposing membranes is reduced from $15 \mathrm{~nm}$ in the control animal to $7.8 \mathrm{~nm}$ in the apo A-I-deficient mouse (Table II). Previous studies by Reaven and colleagues (33) in rat adrenal gland showed that microvillar channels washed free of HDL particles have a width of $7.9 \mathrm{~nm}$ whereas microvillar channels filled with HDL have a width of $15.2 \mathrm{~nm}$. The 7.8-nm channel width observed in the apo A-I-deficient mouse further suggests that these channels are devoid of HDL particles. Thus, despite only a 3.1-fold reduction in plasma HDL-cholesterol concentration, the adrenal microvillar compartment of the apo A-I-deficient animal appears to be essentially devoid of HDL particles.

We also estimated the size of the potential microvillar compartment by measuring the ratio of total microvillar membrane surface length to the linear distance along the subendothelial face of the zona fasciculata parenchymal cell. Measurements from three animals of each genotype showed no significant difference in this ratio (control $2.70 \pm 0.16$; apo A-I-deficient $2.85 \pm 0.34$ ), suggesting that the microvillar compartment has not been increased in the apo A-I-deficient animal.

Cholesteryl ester accumulation in apo E-deficient mice. apo $\mathrm{E}$ is made at high levels by adrenal cells $(32,34,35)$ and is found prominently on the cell surface of zona fasciculata cells (36). Studies with HepG2 cells using monoclonal antibodies to apo E suggest that cell surface apo E may facilitate selective uptake of HDL-cholesteryl esters (37). To determine whether 

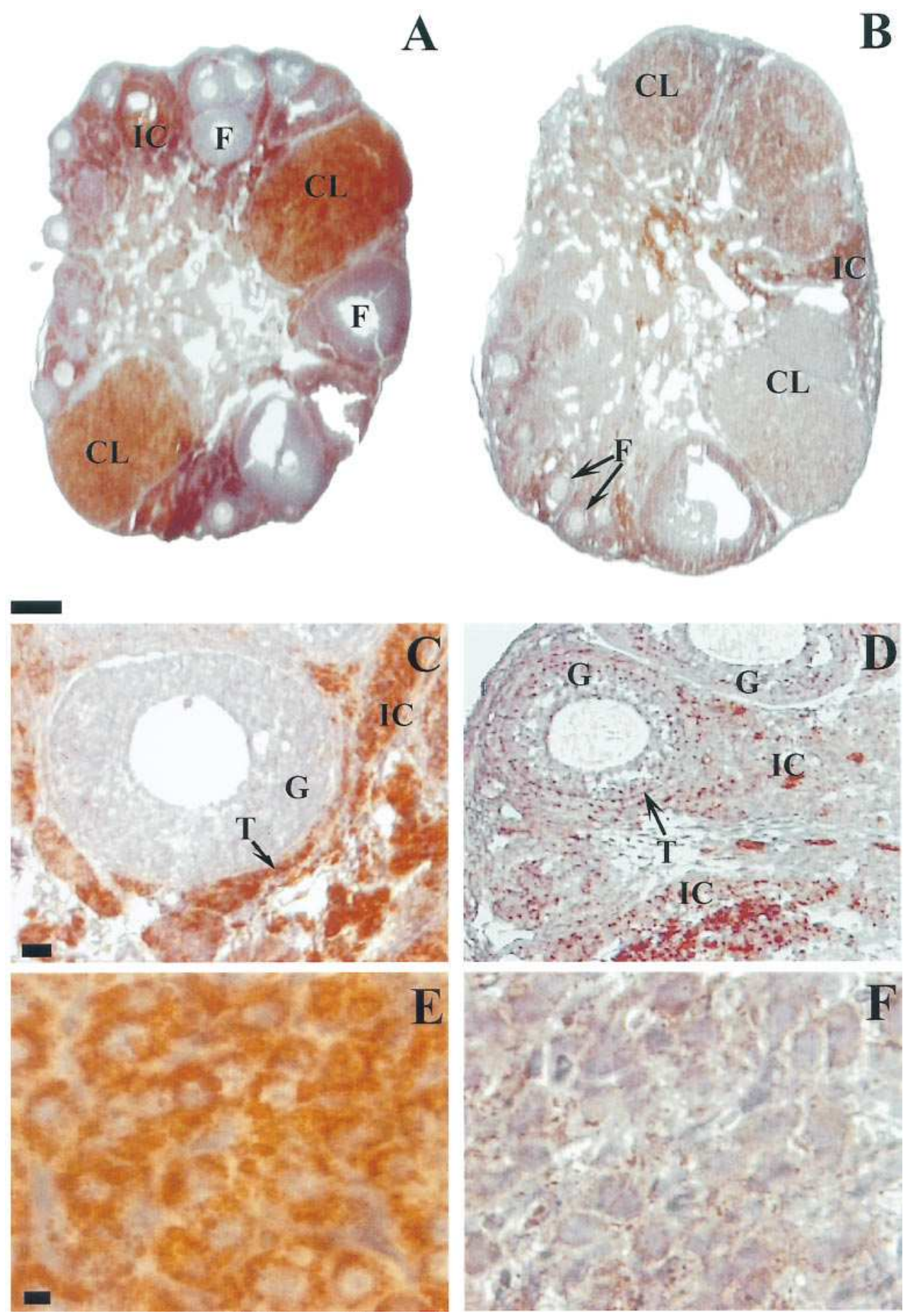

Figure 4. Oil red O staining of wild-type and apo A-I-deficient ovaries. Sections of ovaries from a mature cycling wild-type mouse $(A, C, E)$ and an apo A-I-deficient mouse $(B, D, F)$ were stained with oil red $\mathrm{O}$ and counterstained with hematoxylin. ( $A$ and $B$ ) Luteal $(C L)$ and interstitial cells $(I C)$ of wild-type ovary are heavily stained indicating abundant cholesteryl ester accumulation whereas corresponding cells of apo A-I-deficient ovary are weakly stained; $F$, follicle; scale bar, $250 \mu \mathrm{m}$. ( $C$ and $D$ ) Interstitial and theca $(T)$ cells of wild-type ovary are packed with lipid droplets. Corresponding cells of apo A-I-deficient ovary show either no or few lipid droplets. $G$, granulosa cells; scale bar, $50 \mu \mathrm{m}$. $(E$ and $F$ ) Higher magnification of corpus luteum shows cells packed with cholesteryl ester droplets in wild-type ovary $(E)$ and virtually devoid of droplets in apo A-I-deficient ovary $(F)$. Scale bar, $10 \mu \mathrm{m}$.

apo $\mathrm{E}$ is essential for cholesteryl ester accumulation in adrenocortical cells, oil red $\mathrm{O}$ staining was carried out on adrenal sections from apo E-deficient mice. As shown in Fig. $1 E$, the zona fasciculata and zona reticularis of apo E-deficient mice are comparable in staining intensity to the corresponding cells from wild-type mice (Fig. $1 A$ ). Cholesteryl ester measurements showed no more than $25 \%$ difference in cholesteryl ester content between wild-type and apo E-deficient mice (data not shown) indicating that apo $\mathrm{E}$ is not essential for cholesteryl ester accumulation in adrenal cells. apo E-deficient mice have high levels (400-600 mg/dl) of non-HDL-cholesterol of which
$50-100 \mathrm{mg} / \mathrm{dl}$ is present in the LDL size range that is expected to have access to the microvillar channels of adrenal cells (33). To determine whether such particles can donate cholesterol for cholesteryl ester accumulation, apo A-I-deficient and apo E-deficient mice were crossed, and animals lacking both apo A-I and apo E were analyzed. Despite plasma cholesterol values close to $300 \mathrm{mg} / \mathrm{dl}$ and HDL levels of $10-15 \mathrm{mg} / \mathrm{dl}$ (data not shown), oil red $\mathrm{O}$ staining showed the zona fasciculata and zona reticularis cells (Fig. $1 F$ ) to be as lacking in cholesteryl ester droplets as the corresponding cells in apo A-I-deficient mice (Fig. 1 C). Thus, cholesterol-enriched remnant particles 

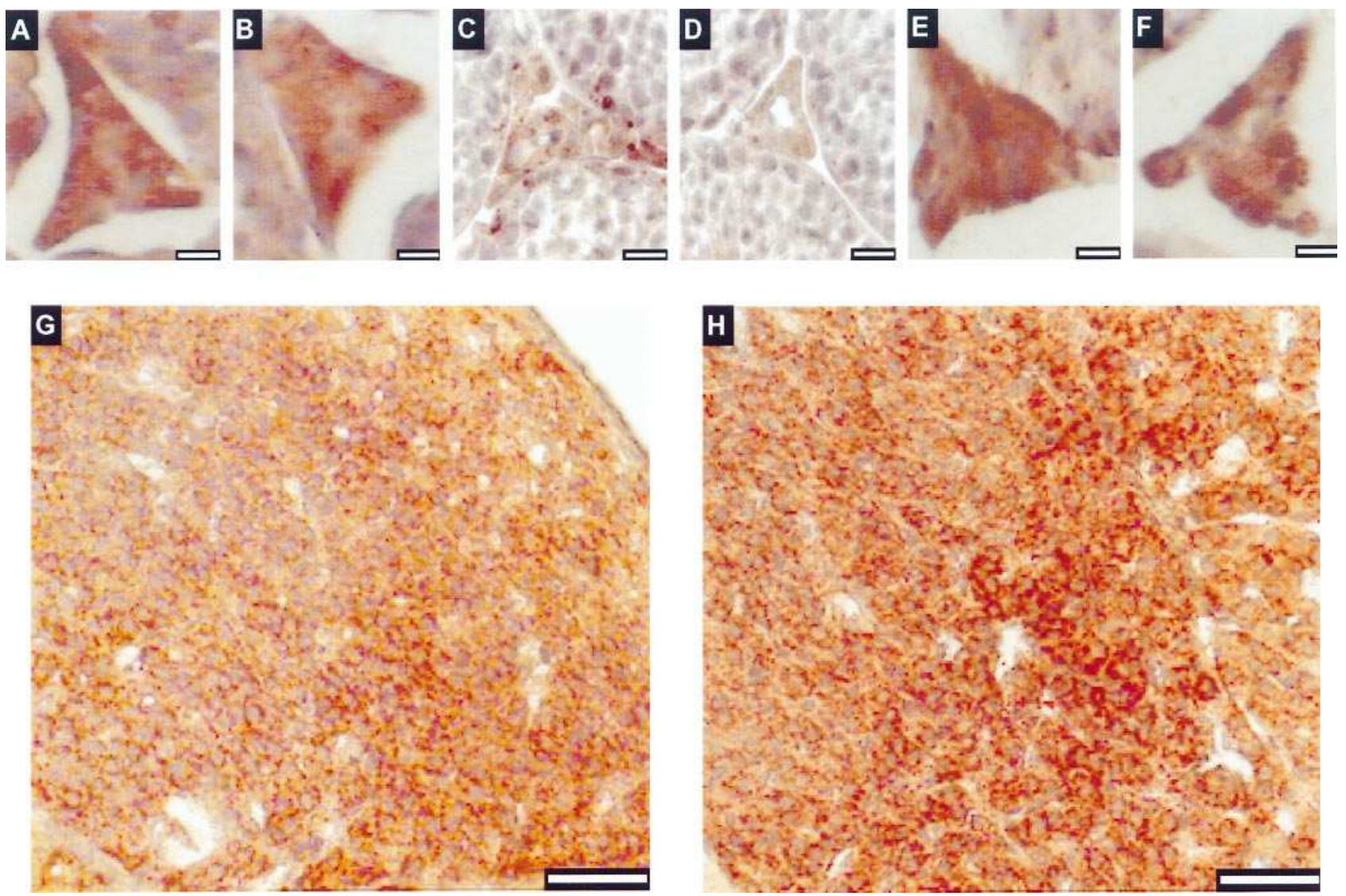

Figure 5. Oil red O staining of Leydig cells and luteal cells. $(A-F)$ Cross sections of testis from wild-type $(A$ and $B)$, apo A-I-deficient $(C$ and $D)$, and apo A-II-deficient $(E$ and $F$ ) mice were stained with oil red $\mathrm{O}$ and counterstained with hematoxylin. Note the heavy staining of the triangular clusters of Leydig cells in the wild-type and apo A-II-deficient mice in contrast to the greatly reduced staining in the apo A-I-deficient mouse. Scale bars, $10 \mu \mathrm{m}$. ( $G$ and $H$ ) Corpus luteum of wild-type $(G)$ and apo A-II-deficient $(H)$ mouse show similar oil red O staining. Scale bars, $50 \mu \mathrm{m}$.

Table I. Adrenal Cholesteryl Ester Accumulation after Dexamethasone Suppression

\begin{tabular}{lccccc}
\hline & \multicolumn{2}{c}{ Wild-type } & & \multicolumn{2}{c}{ apo A-I-deficient } \\
\cline { 2 - 3 } \cline { 5 - 5 } & Male & Female & & Male & Female \\
\hline $\begin{array}{l}\text { Free cholesterol } \\
\quad(\mu \mathrm{g} / \mathrm{mg} \text { tissue weight })\end{array}$ & & & & \\
$\quad$ Saline & $2.4 \pm 0.3$ & $5.1 \pm 0.5$ & & $2.3 \pm 0.1$ & $3.3 \pm 0.4$ \\
$\quad$ DEX & $2.3 \pm 0.2$ & $4.1 \pm 0.3$ & $2.8 \pm 0.1$ & $4.5 \pm 0.1$ \\
Cholesteryl ester & & & & \\
$\quad(\mu g / m g$ tissue weight $)$ & & & & \\
$\quad$ Saline & $14.4 \pm 1.4$ & $42.9 \pm 9.4$ & $0.6 \pm 0.1$ & $2.2 \pm 0.9$ \\
$\quad$ DEX & $26.5 \pm 2.2^{*}$ & $36.5 \pm 5.6$ & $5.9 \pm 0.2^{*}$ & $7.6 \pm 0.9^{*}$ \\
Plasma corticosteroids & & & & \\
$\quad(n g / m l)$ & & & & \\
$\quad$ Saline & $104 \pm 3$ & $265 \pm 97$ & $82 \pm 8$ & $140 \pm 20$ \\
DEX & $24 \pm 1^{*}$ & $151 \pm 46^{\ddagger}$ & $17 \pm 3^{*}$ & $79 \pm 23^{\S}$ \\
& & & & \\
\hline
\end{tabular}

Groups of male $(n=5)$ or female $(n=4)$ mice received saline or dexamethasone $(D E X)$ treatments as described in Methods after which free cholesterol, cholesteryl ester, and serum corticosteroid measurements were made. ${ }^{*} P<0.0001$ compared with the respective saline group; ${ }^{\ddagger} P=$ 0.078 compared with the respective saline group; ${ }^{\S} P=0.007$ compared with the respective saline group. that accumulate in the apo E-deficient state cannot compensate for the absence of apo A-I through either the selective uptake pathway or the LDL receptor pathway. Therefore, the near normal level of adrenal cholesteryl ester in the apo E-deficient mouse is a reflection of the presence of apo A-I and not of remnant accumulation in the absence of apo $\mathrm{E}$.

Adrenal function in apo A-I-deficient mice. To determine if steroidogenic capacity of apo A-I-deficient mice was compromised, plasma corticosteroids were measured in the basal state and in response to stress (Table III). Basal corticosteroid concentrations were reduced by $40 \%$ in male apo A-I-deficient mice but were not changed in females. An acute stress response to a cold water swim test showed that both male and female apo A-I-deficient mice achieve lower plasma corticosteroids than wild-type mice in response to stress (Table III). To test whether this difference lies at the level of the adrenal gland, mice were challenged with a pharmacological dose of ACTH. Male apo A-I-deficient mice showed a blunted response to ACTH with a plasma corticosteroid concentration $60 \%$ of the control value. In contrast, female apo A-I-deficient mice showed no difference in plasma corticosteroids with a single ACTH treatment, but a blunted response at $58 \%$ of the control value was seen with three successive ACTH treatments. The results of basal corticosteroid measurements, the swim stress test, and the ACTH challenge indicate a reduction 


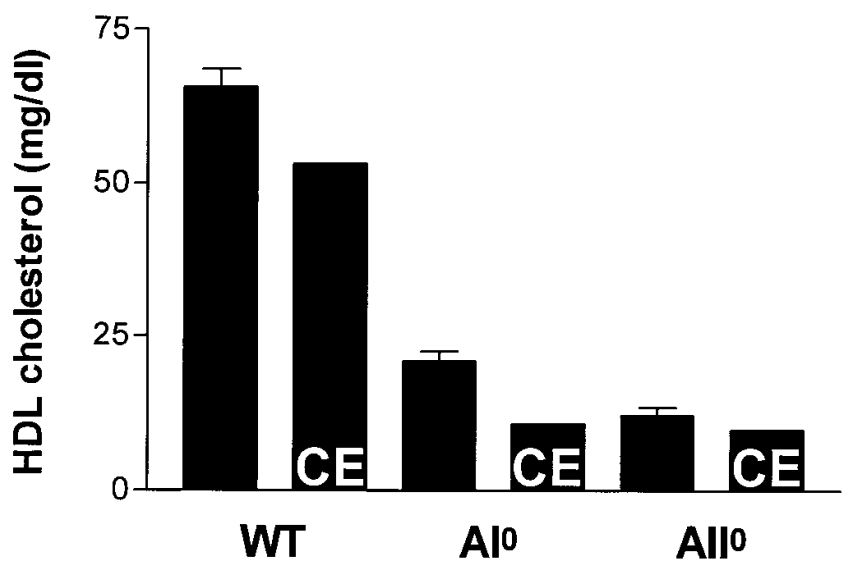

Figure 6. Plasma HDL-cholesterol and HDL-cholesteryl ester. Total cholesterol was measured in HDL isolated from wild-type (WT), apo A-I-deficient $\left(A I^{0}\right)$, and apo A-II-deficient $\left(A I I^{0}\right)$ mice as described in Methods. Adjacent bars show the calculated HDL-cholesteryl ester $(C E)$ determined as the difference between HDL-total and HDLfree cholesterol. Error bars $=\mathrm{SD}$.

in corticosteroid production capacity in apo A-I-deficient mice with male animals more impaired than females.

Despite the absence of cholesteryl ester stores, apo A-Ideficient mice exhibit a reduced corticosteroid response suggesting the use of compensatory pathways to provide cholesterol substrate for steroid production. In addition to obtaining cholesterol from the HDL selective uptake pathway and from endogenous cholesteryl ester stores, adrenocortical cells can synthesize cholesterol and acquire lipoprotein cholesterol via the LDL receptor pathway. To estimate the level of endogenous cholesterol synthesis, the activity of the rate limiting enzyme in the cholesterol biosynthetic pathway, 3-hydroxy3-methylglutaryl coenzyme A (HMG CoA) reductase, was measured. In two experiments (Table IV), adrenal HMG CoA reductase activity was increased by $>67$-fold and $>103$-fold in male and by 5.6- and 5.8-fold in female apo A-I-deficient mice suggesting that cholesterol synthesis is elevated in adrenal glands of apo A-I-deficient mice. LDL receptor levels as measured by Western blot analysis were increased 2.4- and 2.2-fold in apo A-I-deficient males and 1.1- and 1.5-fold in apo A-Ideficient females (Table IV). Because apo $\mathrm{E}$ is made by adrenocortical cells and is also a ligand for the LDL receptor, apo E was measured by Western blot analysis in the same extracts used for LDL receptor measurements. As compared with sex-matched controls, adrenal apo $\mathrm{E}$ levels were increased in apo A-I-deficient mice by 4.7- and 2.4-fold in males and by 2.1- and 1.9-fold in females (Table IV). These results suggest that the LDL receptor pathway is increased in apo A-I-deficient mice. Thus, adrenocortical cells compensate for the loss of apo A-I by upregulating alternate pathways to obtain cholesterol.

\section{Discussion}

The results of this study provide genetic evidence that apo A-I is required for normal cholesteryl ester accumulation in steroidogenic cells of the adrenal gland, ovary, and testis. Since
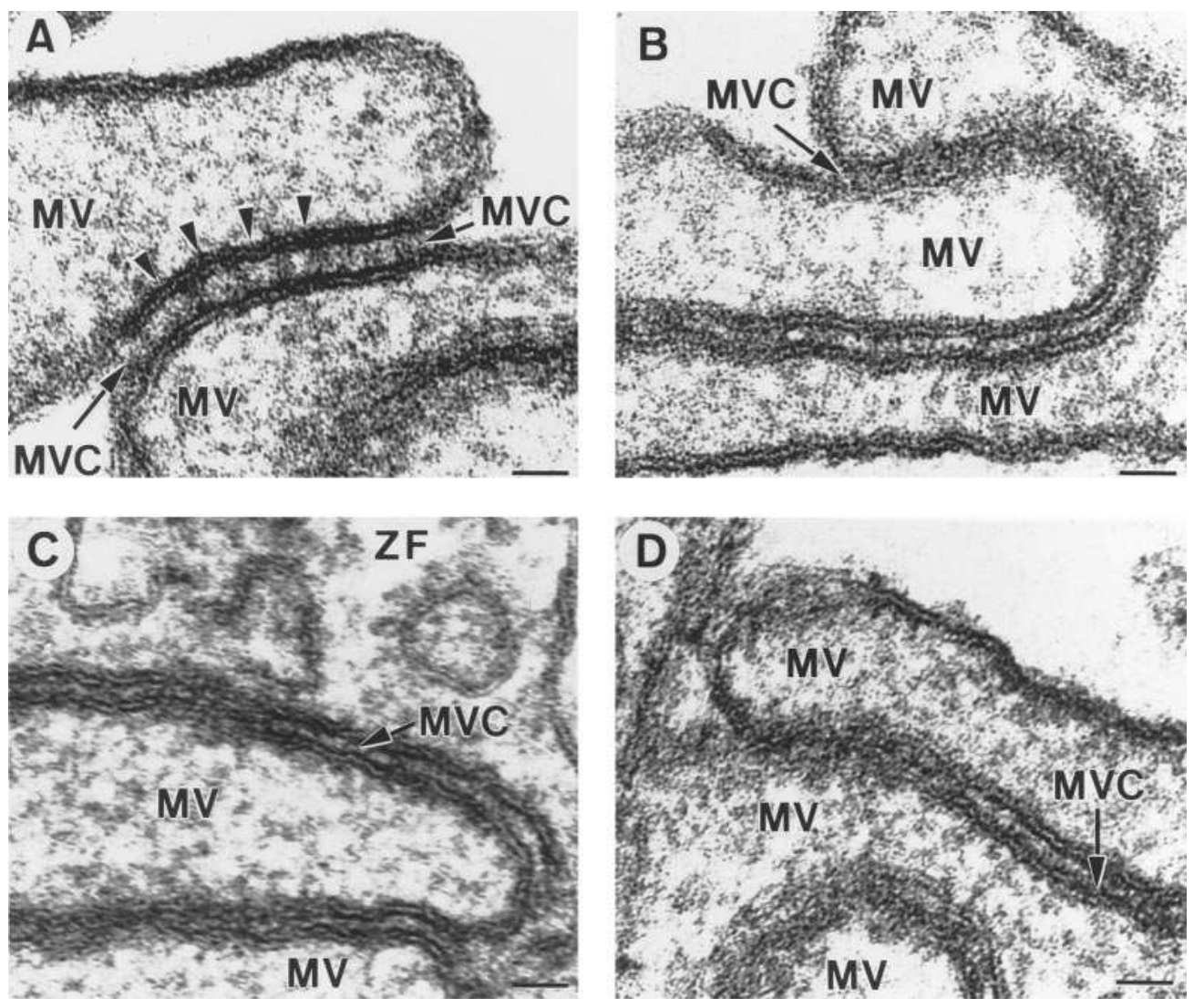

Figure 7. Microvillar channels of wild-type and apo A-I-deficient adrenal glands. $(A) \mathrm{Mi}-$ crovillar channels $(M V C)$ formed by juxtaposed microvilli $(M V)$ of zona fasciculata cells in the subendothelial space of wild-type $(A)$ and apo A-I-deficient adrenal glands $(B-D)$ are shown. Arrowheads in $A$ indicate presumptive HDL particles present in microvillar channels from wild-type mice but not apo A-I-deficient mice. Scale bar, $25 \mathrm{~nm}$. 
Table II. Width of Microvillar Channels

\begin{tabular}{lc}
\hline \multicolumn{1}{c}{ Sample } & Mean \pm SD \\
\hline & $n m$ \\
Wild-type & $15.0 \pm 2.2$ \\
apo A-I-deficient & $7.8 \pm 1.8^{*}$ \\
\hline
\end{tabular}

Microvillar channel measurements (wild-type, $n=160$; apo A-I-deficient, $n=128$ ) were made as described in Methods. ${ }^{*} P<0.0001$ as compared with wild-type.

these cells obtain most of their lipoprotein cholesterol via the HDL-cholesteryl ester selective uptake pathway, these results suggest that apo A-I is critical for selective uptake and/or channeling of HDL-cholesteryl ester to lipid droplets. The role of apo A-I in this process clearly goes beyond its ability to determine HDL levels since apo A-II-deficient mice have similarly reduced HDL levels but only a modest decrease in cholesteryl ester accumulation in steroidogenic cells. In addition, adrenal cholesteryl ester is reduced by 28 - and 25 -fold, respectively, in male and female apo A-I-deficient mice whereas HDL-cholesterol is reduced only 3.1-fold and HDL-cholesteryl ester 5-fold. These data point to a specific role for apo A-I in the HDL-cholesteryl ester selective uptake pathway.

Although the role of apo A-I in the HDL-cholesteryl ester selective uptake pathway is unknown, three possibilities may be suggested. In the first, apo A-I is the HDL ligand responsible for binding to a cell surface receptor directly responsible for the selective uptake of HDL-cholesteryl ester. Previous studies with cultured rat adrenal cells (38) and murine Y1 adrenal cells (39) indicate an apolipoprotein requirement for selective uptake of HDL-cholesteryl ester with a preference for apo A-I-containing as compared with apo E- or apo C-containing HDL particles $(38,39)$. In addition, Gwynne and Mahaffee (40) demonstrated both high and low affinity components to cholesteryl ester uptake by adrenocortical cells, a result consistent with multiple modes of cell surface binding for HDL particles. Although a specific link between an HDL binding site and the selective uptake process has yet to be demonstrated in steroidogenic cells, a recent report identified the scavenger receptor SR-B1 as a potential candidate for a se- lective uptake receptor (41). In the second, apo A-I may bind to a cell surface component that serves to concentrate HDL at the plasma membrane to permit an independent cholesteryl ester transfer process to occur. This would be analogous to the proteoglycan-mediated localization of triglyceride-rich lipoproteins on the endothelial cell to facilitate lipolysis. The finding that apo A-I-deficient mice lack HDL particles within the adrenocortical microvillar channels, the compartment in which selective uptake is believed to occur (33), is consistent with apo A-I acting either as a ligand for a receptor or as a means to localize HDL particles to the cell surface.

A third possibility is that apo A-I is responsible for qualities of the HDL particle that are necessary for the selective uptake of cholesteryl ester. Such qualities could include the surface properties of the particle, the presence or absence of inhibitory apolipoproteins, or the types of cholesteryl esters in the HDL core. Parks et al. (42), for example, have shown that plasma cholesteryl esters in apo A-I-deficient mice are relatively more enriched in saturated fatty acids as compared with the usual enrichment in polyunsaturated fatty acids, reflecting the reduction in lecithin/cholesterol acyltransferase activity in the absence of apo A-I. Using cultured adrenal cells Green and Pittman (43) have shown a greater uptake of cholesteryl ester from HDL particles containing esters enriched in polyunsaturated acyl chains. From the magnitude of these differences $(42,43)$, however, it is unlikely that the altered acyl chain composition of HDL could make more than a modest difference in adrenal cholesteryl ester accumulation in apo A-I-deficient mice. Nevertheless, the influence of such changes in HDL composition has yet to be evaluated in vivo.

The apo A-I-deficient mouse shows a modest impairment in corticosteroid production which is more pronounced in males than females. In males, both basal and stress-induced corticosteroid concentrations were lower in apo A-I-deficient mice, whereas in females reduced plasma corticosteroids were seen only in response to stress. These differences do not appear to have a major physiological impact on the survival of these animals under normal laboratory conditions. However, it remains to be tested whether apo A-I-deficient mice can survive prolonged stress or have other metabolic imbalances due to impaired adrenal function and reduced HDL levels. HDL, for example, is believed to protect against bacterial endotoxin-induced shock (44), an effect that in the context of diminished corticosteroid production might be exaggerated in apo A-I-deficient mice.

Table III. Basal and Stress-induced Plasma Corticosteroids

\begin{tabular}{|c|c|c|c|c|}
\hline & \multicolumn{2}{|c|}{ Wild-type } & \multicolumn{2}{|c|}{ apo A-I-deficient } \\
\hline & Male & Female & Male & Female \\
\hline Basal & $93 \pm 37(n=16)$ & $194 \pm 75(n=9)$ & $58 \pm 18(n=15)^{*}$ & $216 \pm 79(n=8)$ \\
\hline Swim stress test & $194 \pm 23(n=7)$ & $895 \pm 109(n=5)$ & $147 \pm 30(n=6)^{\ddagger}$ & $504 \pm 93(n=5)^{\S}$ \\
\hline \multicolumn{5}{|l|}{ ACTH test } \\
\hline Saline $1 \times$ & $88 \pm 22(n=5)$ & $306 \pm 61(n=4)$ & $65 \pm 9(n=5)^{\|}$ & $198 \pm 61(n=4)^{9}$ \\
\hline ACTH $1 \times$ & $195 \pm 38(n=5)$ & $285 \pm 82(n=4)$ & $126 \pm 22(n=5)^{\ddagger}$ & $233 \pm 57(n=4)$ \\
\hline Saline $3 \times$ & $\mathrm{ND} * *$ & $317 \pm 104(n=4)$ & ND & $218 \pm 57(n=4)$ \\
\hline АСТН $3 \times$ & ND & $361 \pm 91(n=4)$ & ND & $211 \pm 61(n=4)^{\pi}$ \\
\hline
\end{tabular}

Plasma corticosteroids $(\mathrm{ng} / \mathrm{ml})$ were measured in the basal state and in response to a swim stress test and an ACTH test as described in Methods. * $P<$ 0.0001 compared with respective wild-type; ${ }^{\ddagger} P<0.01$ compared with respective wild-type; ${ }^{\S} P<0.001$ compared with respective wild-type; $\| P=0.06$ compared with respective wild-type; ${ }^{q} P<0.05$ compared with respective wild-type; **Not determined. 
Table IV. Adrenal HMG CoA Reductase, LDL Receptor, and apo E Levels

\begin{tabular}{|c|c|c|c|c|}
\hline & \multicolumn{2}{|c|}{ Wild-type } & \multicolumn{2}{|c|}{ apo A-I-deficient } \\
\hline & Male & Female & Male & Female \\
\hline \multicolumn{5}{|c|}{ HMG CoA reductase (pmol mevalonate/min/mg) } \\
\hline Experiment 1 & $<1$ & 7 & 67 & 39 \\
\hline Experiment 2 & $<1$ & 15 & 103 & 87 \\
\hline \multicolumn{5}{|c|}{ LDL receptor (units $/ \mu \mathrm{g}$ ) } \\
\hline Experiment 1 & 0.33 & 0.82 & 0.79 & 0.94 \\
\hline Experiment 2 & 0.13 & 0.91 & 0.28 & 1.39 \\
\hline \multicolumn{5}{|c|}{ Adrenal apo E (units/ $\mu \mathrm{g}$ ) } \\
\hline Experiment 1 & 0.10 & 0.28 & 0.47 & 0.59 \\
\hline Experiment 2 & 0.13 & 0.18 & 0.31 & 0.35 \\
\hline
\end{tabular}

Measurements of HMG CoA reductase, LDL receptor, and apo E were made on adrenal gland microsomes as described in Methods. Each value is the mean of two or more determinations on microsomes prepared from adrenal glands pooled from 10 animals.

Adrenocortical cells normally have four sources from which to draw cholesterol for corticosteroid synthesis: the HDL-selective uptake pathway, endogenous cholesteryl ester stores, the LDL receptor pathway, and de novo cholesterol synthesis. Under normal circumstances, adrenal cells of rodents derive most of their steroidogenic cholesterol precursor from the first two sources $(10,17-19)$. Despite the near absence of adrenal cholesteryl ester and the reduced levels of HDL-cholesterol, apo A-I-deficient mice exhibit an adequate corticosteroid response. Measurements of HMG CoA reductase activity suggest that adrenal cholesterol synthesis is markedly elevated to compensate for the reduction in cholesterol normally supplied by plasma HDL and stored cholesteryl ester. Similarly, increased levels of the LDL receptor and apo E in adrenal glands of apo A-I-deficient mice suggest that the LDL receptor pathway also is upregulated as a compensatory mechanism, although this increase is relatively modest. Thus, adrenocortical cells compensate for the chronic reduction of their major cholesterol sources by upregulating pathways that are normally of minor importance. The compensatory response to apo A-I deficiency to greatly increase HMG CoA reductase activity is similar to that seen in response to the acute reduction of plasma cholesterol induced by 4-aminopyrazolopyrimidine, a drug that blocks hepatic lipoprotein secretion $(17,45)$. In contrast, the increase in the LDL receptor concentration appears more modest in the apo A-I-deficient mouse than occurs in response to 4-aminopyrazolopyrimidine $(18,46)$.

The relative importance of the different lipoprotein cholesterol sources for adrenal steroidogenesis may vary among species. Studies with the Watanabe rabbit which lacks functional LDL receptors, for example, show normal basal corticosteroids, a mildly impaired corticosterone response to ACTH, reduced cytosolic lipid droplets, and increased levels of HMG CoA reductase activity (47). These results suggest adequate compensation in the absence of the LDL receptor pathway. Bovine and ovine adrenal cells in culture can use HDL and LDL to support steroid production $(48,49)$ although data to assess the importance of each pathway in vivo are lacking. Similarly, in humans, some studies have shown that HDL-cho- lesterol can support steroid production by adrenal adenoma and fetal cells in culture although LDL is generally found to be more effective (50-52). Because transformed and fetal cell cultures may not be representative of in vivo function for many reasons, including the fact that LDL receptor expression is very sensitive to cell culture conditions (53), it is difficult to extrapolate cell culture results to humans. Patients homozygous for familial hypercholesterolemia show normal basal corticosteroids and no or only a modest reduction in response to ACTH (54-56) suggesting little effect of removing the LDL receptor pathway. In addition, Lovastatin treatment has no effect on adrenal responsiveness in familial hypercholesterolemic patients $(54,55)$ indicating that either Lovastatin does not effectively inhibit adrenal gland $\mathrm{HMG} \mathrm{CoA}$ reductase or that uptake of HDL-cholesteryl ester provides adrenal cholesterol in humans. In addition, abetalipoproteinemic individuals lacking LDL have normal basal cortisol levels and an ACTH response that is $60 \%$ of normal $(57,58)$. These data also argue that the LDL receptor pathway is not the predominant source of adrenal gland cholesterol in vivo. These results are clearly consistent with a major role for apo A-I and the HDL-cholesteryl ester selective uptake pathway in the human adrenal gland. Studies to evaluate adrenal function in the few kindreds of apo A-I-deficient patients have not been reported. Also lacking are data on adrenal cholesteryl ester accumulation in human subjects lacking either apo A-I or LDL receptors. Consequently, the importance of the HDL-selective uptake pathway in human adrenocortical cholesterol metabolism has yet to be tested.

In contrast to the effect of apo A-I deficiency, adrenal cholesteryl ester accumulation is near normal in apo A-II- and apo $\mathrm{E}$-deficient mice. apo $\mathrm{E}$ is made at high rates by adrenocortical cells $(32,34,35,59)$ and is found prominently on the plasma membrane of zona fasciculata cells in the rat (36). These findings may indicate that apo E facilitates lipoproteincholesterol uptake by adrenal cells by either the LDL receptor pathway or the HDL selective uptake mechanism. If this is the case, the present results suggest that apo E has an accessory rather than a primary role in these processes. Alternatively, apo E may primarily influence the intracellular disposition of cholesterol as seen in murine $\mathrm{Y} 1$ adrenal cells expressing human apo E (60). Interestingly, mice deficient in both apo A-I and apo $E$ fail to accumulate cholesteryl ester in the zona reticularis and zona fasciculata suggesting that cholesteryl esterenriched remnants cannot compensate for the absence of apo A-I through either the selective uptake pathway or the LDL receptor pathway.

Multiple regulated pathways exist to provide cholesterol to steroidogenic cells. The current studies identify apo A-I as a primary determinant of cholesteryl ester accumulation in steroidogenic cells as well as of adrenal gland physiology. Additional studies with animals deficient in one or more apolipoproteins as well as transgenic animals expressing specific apolipoproteins should advance our knowledge of how steroidogenic cells acquire lipoprotein cholesterol through the HDL-cholesteryl ester uptake pathway and how these cells regulate cholesterol metabolism in vivo.

\section{Acknowledgments}

We acknowledge the excellent technical assistance of David Colflesh and Steven Lear. 
This work was supported by National Institutes of Health grants HL-32868 (D.L. Williams) and HL-33714 (J.L. Breslow), and by a grant from the Department of Veterans Affairs (S.K. Erickson).

\section{References}

1. Miller, G.J., and N.E. Miller. 1975. Plasma high density lipoprotein concentration and the development of ischaemic heart disease. Lancet. 1:16-19.

2. Gordon, T., W.P. Castelli, M.C. Hjortland, W.B. Kannel, and T.R. Dawber. 1977. High density lipoprotein as a protective factor against coronary heart disease. Am. J. Med. 62:707-714.

3. Ruben, E.M., R.M. Krauss, E.A. Spangler, J.G. Verstuyft, and S.M. Clift. 1991. Inhibition of early atherosclerosis in transgenic mice by human apolipoprotein AI. Nature (Lond.). 353:265-267.

4. Plump, A.S., C.J. Scott, and J.L. Breslow. 1994. Human apolipoprotein A-I gene expression increases high density lipoprotein and suppresses atherosclerosis in the apolipoprotein E-deficient mouse. Proc. Natl. Acad. Sci. USA. 91:9607-9611.

5. Paszty, C., N. Maeda, J. Verstuyft, and E.M. Rubin. 1994. Apolipoprotein AI transgene corrects apolipoprotein E deficiency-induced atherosclerosis in mice. J. Clin. Invest. 94:899-903.

6. Liu, A.C., R.M. Lawn, J.G. Verstuyft, and E.M. Rubin. 1994. Human apolipoprotein A-I prevents atherosclerosis associated with apolipoprotein[a] in transgenic mice. J. Lipid Res. 35:2263-2267.

7. Glomset, J.A. 1968. The plasma lecithin:cholesterol acyltransferase reaction. J. Lipid Res. 9:155-167.

8. Johnson, W.J., F.H. Mahlberg, G.H. Rothblat, and M.C. Phillips. 1991. Cholesterol transport between cells and high-density lipoproteins. Biochim. Biophys. Acta Lipids Lipid Metab. 1085:273-298.

9. Goldberg, D.I., W.F. Beltz, and R.C. Pittman. 1991. Evaluation of pathways for the cellular uptake of high density lipoprotein cholesterol esters in rabbits. J. Clin. Invest. 87:331-346.

10. Glass, C., R.C. Pittman, M. Civen, and D. Steinberg. 1985. Uptake of high-density lipoprotein-associated apoprotein A-I and cholesterol esters by 16 tissues of the rat in vivo and by adrenal cells and hepatocytes in vitro. J. Biol. Chem. 260:744-750.

11. Pittman, R.C., T.P. Knecht, M.S. Rosenbaum, and C.A. Taylor, Jr. 1987. A nonendocytotic mechanism for the selective uptake of high density lipoprotein-associated cholesterol esters. J. Biol. Chem. 262:2443-2450.

12. Glass, C., R.C. Pittman, D.B. Weinstein, and D. Steinberg. 1983. Dissociation of tissue uptake of cholesterol ester from that of apoprotein A-I of rat plasma high density lipoprotein: selective delivery of cholesterol ester to liver, adrenal, and gonad. Proc. Natl. Acad. Sci. USA. 80:5435-5439.

13. Rinninger, F. and R.C. Pittman. 1988. Regulation of the selective uptake of high density lipoprotein-associated cholesteryl esters by human fibroblasts and Hep G2 hepatoma cells. J. Lipid Res. 29:1179-1194.

14. Stein, Y., Y. Dabach, G. Hollander, G. Halperin, and O. Stein. 1983. Metabolism of HDL-cholesteryl ester in the rat, studied with a nonhydrolyzable analog, cholesteryl linoleyl ether. Biochim. Biophys. Acta. 752:98-105.

15. Rinninger, F., M. Brundert, S. Jackle, P.R. Galle, C. Busch, J.R. Izbicki, X. Rogiers, D. Henne-Burns, B. Kremer, C.E. Broelsch, and H. Greten. 1994. Selective uptake of high-density lipoprotein-associated cholesteryl esters by human hepatocytes in primary culture. Hepatology. 19:1100-1119.

16. Gwynne, J.T., D. Maheffee, H.B. Brewer, Jr., and R.L. Ney. 1976. Adrenal cholesterol uptake from plasma lipoproteins: regulation by corticotropin. Proc. Natl. Acad. Sci. USA. 73:4329-4333.

17. Andersen, J.M., and J.M. Dietschy. 1978. Relative importance of high and low density lipoproteins in the regulation of cholesterol synthesis in the adrenal gland, ovary, and testis of the rat. J. Biol. Chem. 253:9024-9032.

18. Kovanen, P.T., W.J. Schneider, G.M. Hillman, J.L. Goldstein, and M.S. Brown. 1979. Separate mechanisms for the uptake of high and low density lipoproteins by mouse adrenal gland in vivo. J. Biol. Chem. 254:5498-5505.

19. Gwynne, J.T., and B. Hess. 1980. The role of high density lipoproteins in rat adrenal cholesterol metabolism and steroidogenesis. J. Biol. Chem. 255: 10875-10883.

20. Plump, A.S., T. Hayek, A. Walsh, and J.L. Breslow. 1993. Diminished HDL cholesterol ester flux in apoA-I-deficient mice. Circulation. 88:2266a. (Abstr.)

21. Weng, W., T. Hayek, and J.L. Breslow. 1995. Dramatic reduction of high density lipoprotein in apolipoprotein A-II deficient mice created by homologous recombination in ES cells. Circulation. 92:492a. (Abstr.)

22. Plump, A.S., J.D. Smith, T. Hayek, K. Aalto-Setälä, A. Walsh, J.G. Verstuyft, E.M. Rubin, and J.L. Breslow. 1992. Sever hypercholesterolemia and atherosclerosis in apolipoprotein E-deficient mice created by homologous recombination in ES cells. Cell. 71:343-353.

23. Smythe, G.A., J.E. Bradshaw, and R.F. Vining. 1983. Hypothalamic monoamine control of stress-induced adrenocorticotropin release in the rat. Endocrinology. 113:1062-1067.

24. Doering, C.H., J.G.M. Shire, S. Kessler, and R.B. Clayton. 1972. Cholesterol ester concentration and corticosterone production in adrenals of C57BL/
10 and DBA/2 strains in relation to adrenal lipid depletion. Endocrinology. 90: 93-101.

25. Coalson, R.E. 1981. Staining methods for cell types in endocrine glands. In Staining Procedures. G. Clark, editor. Williams and Wilkins, Baltimore. 228 229.

26. Kowal, J., and R. Fiedler. 1968. Adrenal cells in tissue culture. I. Assay of steroid products. Arch. Biochem. Biophys. 128:406-421.

27. Erickson, S.K., S.R. Lear, M.A. Barker, and T.A. Musliner. 1990. Regulation of cholesterol metabolism in the ethionine induced premalignant rat liver. J. Lipid Res. 31:933-945.

28. Voyno-Yasenetskaya, T.A., L.G. Dobbs, S.K. Erickson, and R.L. Hamilton. 1993. Low density lipoprotein- and high density lipoprotein-mediated signal transduction and exocytosis in alveolar type II cells. Proc. Natl. Acad. Sci. USA. 90:4256-4260.

29. Havel, R.J., H.A. Eder, and J.H. Bragdon. 1955. The distribution and chemical composition of ultracentrifugally separated lipoproteins in human serum. J. Clin. Invest. 34:1345-1353.

30. Moses, H.L., W.W. Davis, A.S. Rosenthal, and L.D. Garren. 1969. Adrenal cholesterol: localization by electron-microscope autoradiography. Science (Wash. DC). 163:1203-1205.

31. Sand, G., J. Frühling, W. Penasse, and A. Claude. 1972. Distribution du cholestérol dans la corticosurrénale du rat: analyse morphologique et chimique des fractions subcellulaires, isolées par centrifugation différentielle. J. Microsc. 15:41-66.

32. Nicosia, M., M.M. Prack, and D.L. Williams. 1992. Differential regulation of apolipoprotein E mRNA in z. fasciculata cells of rat adrenal gland determined by in situ hybridization. Mol. Endocrinol. 6:288-298.

33. Reaven, E., M. Spicher, and S. Azhar. 1989. Microvillar channels: a unique plasma membrane compartment for concentrating lipoproteins on the surface of rat adrenal cortical cells. J. Lipid Res. 30:1551-1560.

34. Blue, M.-L., D.L. Williams, S. Zucker, S.A. Khan, and C.B. Blum. 1983. Apolipoprotein E synthesis in human kidney, adrenal gland, and liver. Proc Natl. Acad. Sci. USA. 80:283-287.

35. Williams, D.L., P.A. Dawson, T.C. Newman, and L.L. Rudel. 1985. Apolipoprotein E synthesis in peripheral tissues of nonhuman primates. J. Biol. Chem. 260:2444-2451.

36. Williams, D.L., J.S. Wong, S.L. Wissig, and R.L. Hamilton. 1995. Cell surface "blanket" of apolipoprotein E on rat adrenocortical cells. J. Lipid Res. 36:745-758.

37. Leblond, L., and Y.L. Marcel. 1993. Uptake of high density lipoprotein cholesterol ester by hepG2 cells involves apolipoprotein $\mathrm{E}$ localized on the cell surface. J. Biol. Chem. 268:1670-1676.

38. Leitersdorf, E., A. Israeli, O. Stein, S. Eisenberg, and Y. Stein. 1986. The role of apolipoproteins of HDL in the selective uptake of cholesteryl linoleyl ether by cultured rat and bovine adrenal cells. Biochim. Biophys. Acta. 878: 320-329.

39. Pittman, R.C., C.K. Glass, D. Atkinson, and D.M. Small. 1987. Synthetic high density lipoprotein particles. Application to studies of the apoprotein specificity for selective uptake of cholesterol esters. J. Biol. Chem. 262:24352442 .

40. Gwynne, J.T., and D.D. Mahaffee. 1989. Rat adrenal uptake and metabolism of high density lipoprotein cholesteryl ester. J. Biol. Chem. 264:81418150 .

41. Acton, S., A. Rigotti, K.T. Landschulz, S. Xu, H.H. Hobbs, and M. Krieger. 1996. Identification of scavenger receptor SR-B1 as a high density lipoprotein receptor. Science (Wash. DC). 271:518-520.

42. Parks, J.S., H. Li, A.K. Gebre, T.L. Smith, and N. Maeda. 1995. Effect of apolipoprotein A-I deficiency on lecithin:cholesterol acyltransferase activation in mouse plasma. J. Lipid Res. 36:349-355.

43. Green, S.R., and R.C. Pittman. 1991. Comparative acyl specificities for transfer and selective uptake of high density lipoprotein cholesteryl esters. $J$. Lipid Res. 32:457-467.

44. Levine, D.M., T.S. Parker, T.M. Donnelly, A. Walsh, and A.L. Rubin. 1993. In vivo protection against endotoxin by plasma high density lipoprotein. Proc. Natl. Acad. Sci. USA. 90:12040-12044.

45. Brown, M.S., P.T. Kovanen, and J.L. Goldstein. 1979. Receptor mediated uptake of lipoprotein-cholesterol and its utilization for steroid synthesis in the adrenal cortex. Rec. Prog. Horm. Res. 35:215-257.

46. Kovanen, P.T., J.L. Goldstein, D.A. Chappell, and M.S. Brown. 1980. Regulation of low density lipoprotein receptors by adrenocorticotropin in the adrenal gland of mice and rats in vivo. J. Biol. Chem. 255:5591-5598.

47. Hoeg, J.M., L. Loriaux, R.E. Gregg, W.R. Green, and H.B.J. Brewer. 1985. Impaired adrenal reserve in the Watanabe heritable hyperlipidemic rabbit: implications for LDL-receptor function in steroidogenesis. Metab. Clin. Exp. 34:194-197.

48. Rainey, W.E., R.J. Rodgers, and J.I. Mason. 1992. The role of bovine lipoproteins in the regulation of steroidogenesis and HMG-CoA reductase in bovine adrenocortical cells. Steroids. 57:167-173.

49. Durand, P., A.M. Cathiard, E. Naaman, V. Brieu, and J.M. Saez. 1987. The influence of plasma lipoproteins on steroidogenesis of cultured ovine fetal and neonatal adrenal cells. J. Steroid Biochem. 26:425-431.

50. Higashijima, M., K. Kato, H. Nawata, and H. Ibayashi. 1987. Studies on 
lipoprotein and adrenal steroidogenesis. II. Utilization of low density lipoprotein- and high density lipoprotein-cholesterol for steroid production in functioning human adrenocortical adenoma cells in culture. Endocrinol. Jpn. 34: 647-657.

51. Higashijima, M., H. Nawata, K. Kato, and H. Ibayashi. 1987. Studies on lipoprotein and adrenal steroidogenesis. I. Roles of low density lipoproteinand high density lipoprotein-cholesterol in steroid production in cultured human adrenocortical cells. Endocrinol. Jpn. 34:635-645.

52. Carr, R.R., and E.R. Simpson. 1981. Lipoprotein utilization and cholesterol synthesis by the human fetal adrenal gland. Endocr. Rev. 2:306-326.

53. Goldstein, J.L., S.K. Basu, and M.S. Brown. 1983. Receptor-mediated endocytosis of low-density lipoprotein in cultured cells. Methods Enzymol. 98: $241-260$

54. Laue, L., J.M. Hoeg, K. Barnes, D.L. Loriaux, and G.P. Chrousos. 1987. The effect of mevinolin on steroidogenesis in patients with defects in the low density lipoprotein receptor pathway. J. Clin. Endocrinol. \& Metab. 64:531-535.

55. Boizel, R., E. de Peretti, A.M. Cathiard, S. Halimi, M. Bost, F. Berthezene, and J.M. Saez. 1986. Pattern of plasma levels of cortisol, dehydoepiandrosterone and pregnenolone sulphate in normal subjects and in patients with homozygous familial hypercholesterolemia during ACTH infusion. Clin. Endocrinol. 25:363-371.

56. Allen, J.M., G.R. Thompson, and N.B. Myant. 1983. Normal adrenocortical response to adrenocorticotrophic hormone in patients with homozygous familial hypercholesterolemia. Clin. Sci. 65:99-101.

57. Illingworth, D.R., E.S. Orwoll, and W.E. Connor. 1980. Impaired cortisol secretion in abetalipoproteinemia. J. Clin. Endocrinol. \& Metab. 50:977979.

58. Illingworth, D.R., T.A. Kenny, and E.S. Orwoll. 1982. Adrenal function in heterozygous and homozygous hypobetalipoproteinemia. J. Clin. Endocrinol. \& Metab. 54:27-33.

59. Prack, M.M., M. Nicosia, D.L. Williams, and J. Gwynne. 1991. Relationship between apolipoprotein E mRNA expression and tissue cholesterol content in rat adrenal gland. J. Lipid Res. 32:1611-1618.

60. Prack, M.M., G.H. Rothblat, S.K. Erickson, M.E. Reyland, and D.L. Williams. 1994. Apolipoprotein E expression in Y1 adrenal cells is associated with increased intracellular cholesterol content and reduced free cholesterol efflux. Biochemistry. 33:5049-5055. 